\title{
Improving Biocontrol of Damping-off, Root Rot and/or Wilt Diseases of Faba Bean by Salicylic Acid and Hydrogen Peroxide \\ M.F. Abdel-Monaim
}

Plant Pathol. Res. Inst., Agric. Res. Centre, Giza, Egypt.

Phizoctonia solani, Fusarium solani, F. oxysporum and Macrophomina phaseolina were found to be associated with root rot and/or wilt symptoms of faba bean plants collected from different fields in New Valley Governorate, Egypt. All the obtained isolates were able to attack faba bean plants (cv. Giza 40) causing dampingoff, root rot and wilt diseases. Pathogenicity test revealed that five isolates, i.e. two of $R$. solani (No. 2 and 5), one of F. solani (No. 8), one of $F$. oxysporum (No. 12) and one of M. phaseolina (No. 14), were the most virulent ones on faba bean plants.

The bioagents Bacillus megaterium and Trichoderma viride as well as the inducer chemicals salicylic acid and hydrogen peroxide were examined, either individually or in combinations, for controlling damping-off, root rot and/or wilt diseases, in addition to their in vitro and in vivo effects as growth promotions on faba bean plants. All bioagents and inducer chemicals applied either individually or in combinations, inhibited the growth of the tested pathogenic fungi. Bioagents combined with inducer chemicals recorded the highest inhibition, especially in case of $\mathrm{SA}+T$. viride and $\mathrm{SA}+$ B. megaterium. Under greenhouse and field conditions, all treatments significantly reduced damping-off, root rot and/or wilt diseases and increased the survived plants. Also, in pots experiment, tested treatments increased fresh and dry weight of the survived plants compared to the control treatment. Moreover, combinations of the tested bioagents and inducer chemicals were more effective than using each of them individually. Treatment of $\mathrm{SA}+T$. viride recorded the best results in this respect.

Under field conditions, all tested treatments significantly increased growth parameters (plant height and No. of branches/plant) and yield components (No. of pods and seeds/ plant, weight of 100 seeds and total yield/feddan) and protein content in both growing seasons of 2010/11 and 2011/12. Faba bean seeds soaked in SA + $T$. viride and $\mathrm{SA}+B$. megaterium recorded the highest growth parameters and yield components.

Generally, the combination between the bioagents and inducer chemicals recoded the best results for controlling damping-off, root rot and wilt diseases under the greenhouse and the field conditions, in addition to improve plant growth and increase yield components, protein content in seeds under field conditions.

Keywords: Bacillus megaterium, biological control, faba bean, hydrogen peroxide, root rot, salicylic acid and Trichoderma viride and wilt. 
Faba bean (Vicia faba L.) is known as an important human food in developing countries. It is also used as an animal feed, mainly for pigs, horses, poultry and pigeons in industrialized countries. Feeding value of faba bean is high and this legume has been considered as a meat extender or substitute due to its high protein content (20-41\%) (Chaven et al., 1989). Root rot and wilt diseases, caused by several soil-borne fungal pathogens, are wide spread on many crops cultivated in different soil types. Faba bean is subjected to attack by many pathogenic organisms, wherever the crop is grown. Several root rot and wilt pathogens such as Rhizoctonia solani, Fusarium solani and Macrophomina phaseolina are reported to attack faba bean roots and stem base causing serious losses in seed germination and plant stand as well (Abdel-Kader et al., 2011).

An investigation for controlling such diseases is considered important, especially in view of their wide prevalence in Egypt. Several attempts to control root rot and wilt diseases could be accepted. However, fungicides are considered as one of several factors involving in environmental pollution, in spite of their satisfactory results in the control of plant diseases. In addition, controlling plant diseases with fungicides has proven very difficult and almost all fungicides are effective only at phytotoxic levels (Jarvis, 1988). Recently, the growing concern over the use of pesticides to human health and environment has brought increasing interest in the use of alternatives methods with negative impact on the environment. Therefore, the present activity focuses on finding compounds that are safe to human and environment. An alternative to fungicidal application, it may be possible to utilize a scheme of inducible plant defences which provides protection against a broad spectrum of disease-causing organisms. Among synthetic inducers, salicylic acid (SA) and hydrogen peroxide $\left(\mathrm{H}_{2} \mathrm{O}_{2}\right)$ have been found to be active as antimicrobial agents in various trials as disease resistance inducers. These have been reported for inducing resistance against several plant pathogens, i.e. F. oxysporum on tomato (Abdel-Monaim et al., 2012), R. solani on faba bean and potato (Metwally, 2004), F. solani on lentil (Morsy, 2005) and M. phaseolina on watermelon (Saleh et al., 2009). On the other hand, the application of biological control using antagonistic microorganisms proved to be successful for controlling various plant diseases in many countries. Biological control is proposed to be an effective and non-hazardous strategy to reduce crop damage caused by plant pathogens. In recent years $B$. megaterium and $T$. viride have been extensively used for plant growth promotion and disease control (Abdel-Monaim, 2010). Biological control of soil-borne pathogens is often attributed to improve nutrition that boosts host defences or to direct inhibition of pathogen growth and activity. Amendment with certain abiotic factors (inducers) appears to stimulate the disease resistance by indirectly stimulating indigenous populations of microorganisms that are beneficial to plant growth and antagonistic to the pathogens. For example chitin amendment of soil has been found to stimulate the growth of chitinolytic microorganisms (De Boer et al., 1999), increases the biocontrol activity and stimulates the expression of plant defence proteins (Roby et al., 1987). All these effects may culminate in enhancing plant protection. Similarly, salicylic acid (SA) and $\mathrm{H}_{2} \mathrm{O}_{2}$ amendment was tested in combination with the bioagents. Saikia et al. (2003) found that applying

Egypt. J. Phytopathol., Vol. 41, No. 2 (2013) 
P. fluorescens, with or without SA amendment, highly protected chickpea seedlings against Fusarium wilt.

Thus, the aim of this study is to (i) screen bioagents and inducer chemicals individually or in combination in a capable of inhibiting the growth of the tested fungi, (ii) determine the biocontrol efficiency of $B$. megaterium and T. viride, either alone or in combination with the inducer chemicals against damping-off, root rot and wilt diseases, and (iii) evaluate the effect of $B$. megaterium and $T$. viride, alone or in combination with the inducer chemicals amendment on promoting growth and yield components of faba bean in the field.

\section{Materials and Methods}

Isolation, purification and identification of the causal organisms:

Faba bean plants showing root rot and wilt symptoms were collected from different farms located in New Valley Governorate. The infected roots were thoroughly washed with running tap water, cut into small fragments, superficially sterilized with sodium hypochlorite $(5 \%)$ for 2 min., washed several times with sterile distilled water and dried between sterilized filter paper. The sterilized pieces were transferred into potato dextrose agar (PDA) medium supplemented with penicillin $\left(20 \mathrm{ul} \mathrm{ml}^{-1}\right)$ and incubated at $25 \pm 1^{\circ} \mathrm{C}$. The dishes were examined daily for fungal growth. The fungal colonies were purified using signal spore or hyphal tip techniques suggested by Booth (1985) and Dhingra and Sinclair (1985) and then identified according to their morphological and microscopical characters as described by Booth (1985), Barnett and Hunter (1986). Identification was confirmed by Assuit University Mycological Centre (AUMC), Assiut Univ., Assuit, Egypt. The obtained isolates were maintained on PDA slants and kept in a refrigerator at $5^{\circ} \mathrm{C}$ for further study.

Pathogenicity test:

The pathogenicity test of the obtained fungal isolates was carried out at New Valley Agric. Res. Station, on faba bean (cv. Giza 40) in pots contained soil infested with any of the tested fungi using homogenized culture technique according to Muthomi et al. (2007).

Preparation of the fungal inocula:

The inoculum of the obtained isolates was prepared from one week old cultures grown on $50 \mathrm{ml}$ potato dextrose broth medium (PDB) in Conical flasks $(250 \mathrm{ml})$ and incubated at $25 \pm 1^{\circ} \mathrm{C}$. The content of each flask was homogenized in a blender for one min. Plastic pots were filled with formalin sterilized soil and mixed with fungal inoculum at the rate of $100 \mathrm{ml}$ homogenized culture per pot, seven days before planting. Five pots were used as replicates per isolate and another 5 pots with equal amount of sterile PDB medium without fungal inoculation were severed as control. Five sterilized surface seeds were sown in each pot. Damping-off percentages were recorded 30 days after sowing. Meanwhile, the severity of root rot and wilt was determined 90 days after sowing according to Abdou et al. (2001) using a rating scale of 0 to 5 on the basis of root discoloration or leaf yellowing as follows: 
$0=$ neither root discoloration nor leaf yellowing.

$1=1-25 \%$ root discoloration or one leaf yellowed.

$2=26-50 \%$ root discoloration or more than one leaf yellowed.

$3=51-75 \%$ root discoloration plus one leaf wilted.

$4=$ up to $76 \%$ root discoloration or more than one leaf wilted.

$5=$ completely dead plants.

For each replicate a disease severity index (DSI) similar to that one described by Liu et al. (1995) was calculated as follows:

$$
\text { DSI= } \frac{\sum \mathrm{d}}{\mathrm{D} \max \times \mathrm{x}}
$$

Whereas: $\mathrm{d}=$ Possible disease rating, $\mathrm{d} \max =$ Maximum disease rating and $\mathrm{n}=$ Total number of plants examined in each replicate.

In vitro studies:

Two antagonistic organisms, i.e. Bacillus megaterium (isolate BSM5) and Trichoderma viride (isolate TVM2), previously isolated by the Abdel-Monaim (2010), were used in this study. Meanwhile, the inducer chemicals salicylic acid (SA) and hydrogen peroxide $\left(\mathrm{H}_{2} \mathrm{O}_{2}\right)$ were prepared at concentration of 4 and $1 \mathrm{mM}$, respectively. The effect of both bioagents and inducer chemicals, individually and/or in combination, was studies as follows:

Efficacy of the antagonistic bioagents:

Trichoderma viride as well as the tested pathogenic fungi, i.e. R. solani, F. solani and M. phaseolina were cultured on PDA medium for 5 days at $25 \pm 1^{\circ} \mathrm{C}$. A disc (0.5-cm-diameter) of the antagonistic fungal colony was cut and placed opposite to the colony of the pathogenic fungal isolates on PDA medium at the same distance from the edge of the plate. On the other hand, B. megaterium isolate was streaked at opposite ends of PDA plates near edge and incubated at $25 \pm 1^{\circ} \mathrm{C}$ for $24 \mathrm{~h}$. Mycelial disc $(0.5-\mathrm{cm}$-diam.) of any of the tested fungi was placed in the centre of each plate.

Efficacy of inducer chemicals:

The effect of tested inducer chemicals on the growth of the pathogenic isolates was carried out using PDA medium. Twenty $\mathrm{ml}$ of PDA medium containing $4 \mathrm{mM}$ $\mathrm{SA}$ or $1 \mathrm{mM} \mathrm{H}_{2} \mathrm{O}_{2}$ was poured in each plate and inoculated with any of the pathogenic fungi. Plates containing PDA medium free from any inducer chemicals were used as control.

Efficacy of combination between the bioagents and inducer chemicals:

Flasks $(250 \mathrm{ml})$ containing $200 \mathrm{ml}$ of PDA medium were amended with $4 \mathrm{mM}$ SA or $1 \mathrm{mM} \mathrm{H}_{2} \mathrm{O}_{2}$ individually, then each flask was poured in 10 plates. These plates were inoculated with the antagonistic and pathogenic isolates as mentioned before. For control treatment, the agar plug of only pathogen isolates was placed on PDA plates. The inoculated plates were incubated at $25 \pm 1^{\circ} \mathrm{C}$ until colonies of control grow to fill the plate. At this point, colony diameter was measured using ruler, where the percentage of growth inhibition of the pathogen was calculated using the following formula: Inhibition $(\%)=(A-B) / A \times 100$ 
Whereas: $\mathrm{A}=$ Colony diam. of pathogen in the control and $\mathrm{B}=$ Colony diam. in treated plates.

In vivo studies:

Greenhouse experiments:

The effect of the tested bioagents and inducer chemicals individually or in combination against faba bean damping-off and root rot diseases incited by $R$. solani, F. solani and M. phaseolina was evaluated under greenhouse conditions. Ten $\mathrm{ml}$. of sterilized water was added to the growth of $T$. viride in each plate, grown on PDA at $25 \pm 1^{\circ} \mathrm{C}$ for 7 days, to prepare a concentration of $10^{6} \mathrm{cfu} / \mathrm{ml}$. Cell suspension of $B$. megaterium grown on nutrient broth medium for 2 days at $25 \pm 1^{\circ} \mathrm{C}$ was adjusted to $2.5 \times 10^{8} \mathrm{cfu} / \mathrm{ml}$. SA and $\mathrm{H}_{2} \mathrm{O}_{2}$ were prepared at 4 and $1 \mathrm{mM}$, respectively. The combination between the bioagents and inducer chemicals was prepared by dissolving inducer chemicals in the suspension of each of the tested bioagents. Faba bean seeds were soaked for $6 \mathrm{hr}$. in the following treatments:

1- T. viride $\left(10^{6} \mathrm{cfu} / \mathrm{ml}\right), 2-$ B. megaterium $\left(2.5 \times 10^{8} \mathrm{cfu} / \mathrm{ml}\right), 3-\mathrm{SA}(4 \mathrm{mM})$, 4- $\mathrm{H}_{2} \mathrm{O}_{2}(1 \mathrm{mM})$, 5- $\mathrm{SA}+T$. viride, 6- $\mathrm{SA}+B$. megaterium, 7- $\mathrm{H}_{2} \mathrm{O}_{2}+T$. viride, 8- $\mathrm{H}_{2} \mathrm{O}_{2}+$ B. megaterium and 9- Control.

Plastic pots (30-cm-diam.) were filled with sterilized soil and mixed with fungal inoculum at rate $100 \mathrm{ml}$ homogenized culture per pot, seven days before planting. Six seeds were sown in each pot and five pots were used for each treatment. In control treatment, faba bean seeds were soaked in water only for $6 \mathrm{hrs}$ and sown at the same rate. Also, treated and untreated seeds were sown in pots contained uninfested soil to study the effect of these treatments on plant growth.

All pots were examined 30 and 90 days after sowing to record the percentage of damping-off and root rot and/or wilt severity, respectively. Also, at the end of the experiment, the survived plants were weighed to record fresh and dry weight per plant.

\section{Field experiments:}

Field experiments were carried out at New Valley Res. Station Farm during $2009 / 10$ and 2010/11 growing seasons, to evaluate the efficiency of the tested bioagents and inducer chemicals, individually or in combination on controlling damping-off and root rot diseases as well as their effect on growth and yield parameters. The experimental design was a complete randomized block with three replicates. The experimental unit area was $10.5 \mathrm{~m}^{2}(3.5 \times 3 \mathrm{~m})$. Each unit included 5 rows; each row was $3.5 \mathrm{~m}$ in length and $60 \mathrm{~cm}$ width. Faba bean seeds (cv. Giza 40) were soaked in the preparation of the tested bioagents and inducer chemicals as described before. Two seeds were sown in each hill with $25 \mathrm{~cm}$ apart on both sides of $6 \mathrm{~cm}$ ridges in both seasons. In control treatment, faba bean seeds were soaked in water only for $6 \mathrm{hr}$. and sown at the same rate. The normal agricultural practices of growing faba bean were followed.

Damping-off percentages as well as root rot and/or wilt severity were recorded 30 and 90 days after sowing. At harvest time, plant height $(\mathrm{cm})$, number of branches, pods and seeds/plant, 100 seed weight and total yield ( $\mathrm{kg}$ feddan) were estimated. Protein content in the seeds was assessed using the method of Jackson (1973). 
Statistical analysis:

Analyses of variance were carried out using MSTAT-C program version 2.10 (Anonymous, 1991). Least significant difference (LSD) was employed to test for significant difference between treatments at P $₫ .05$ (Gomez and Gomez, 1984).

\section{Res u l t s}

Isolation purification and identification of the causal organisms:

Twenty isolates of different soil-borne fungi listed in Table (1) were isolated from wilted and rotten roots of faba bean plants, showed root-rot and/or wilt symptoms collected from different fields in New Valley Governorate. The isolated fungi were purified and identified as F. oxysporum (4 isolates), Fusarium solani (4 isolates), Macrophomina phaseolina (4 isolates) and Rhizoctonia solani (5 isolates), as well as 3 unidentified isolates.

Pathogenicity test:

Results presented in Table (1) reveal that all the tested isolates infected the roots of faba bean plants causing damping-off, root rot and/or wilt symptoms. The highest damping-off infection (60\%) was recorded by $R$. solani (isolate 2 ) followed by $F$. solani isolate $8(56 \%)$ then both $R$. solani isolate 3 and $F$. solani isolate 9 (being $52 \%$ ). On the other hand, all the tested isolates caused root rot and/or wilt ranging between $2.59-50.7 \%$. F . oxysporum isolates 12 and 13 followed by $R$. solani isolate 5 caused the highest root rot and/or wilt, being 50.67, 44.33 and $39.67 \%$, respectively. Moreover, obtained results indicated that $R$. solani isolates 2 and 5, $F$. solani isolate $8, F$. oxysporum isolate 12 and $M$. phaseolina isolate 14 were the most virulent ones, where they recoded the lowest survived plants, being 4.33, $16.33,10.4,13.33$ and $21.33 \%$, respectively. Therefore, the highly pathogenic fungal isolates, i.e. R. solani (2), F. solani (8), F. oxysporum (12) and M. phaseolina (14) were chosen to carry out the further studies based on their pathogenic abilities.

Effect of antagonists and inducer chemicals on the linear growth:

Data in Table (2) indicate that the tested bioagents and the inducer chemicals either individually or in combination significantly reduced the linear growth of all the tested fungi. In general, the combination between the bioagents and the inducer chemicals was more effective than using any of them individually. In addition, $\mathrm{SA}+T$. viride and $\mathrm{SA}+B$. megaterium were the most effective treatments, where they recorded the highest percentages of reduction in the linear growth. On the other hand, SA followed by $\mathrm{H}_{2} \mathrm{O}_{2}$ recoded the lowest reduction in the growth of all the tested fungi. Furthermore, the bioagents were more efficient in reducing the linear growth of the tested pathogenic fungi than the inducer chemicals.

Greenhouse experiments:

Effect of the bioagents and inducer chemicals on damping-off incidence:

Data presented in Table (3) show that all treatments significantly reduced damping-off and root rot and/or wilt of faba bean artificially inoculated with the tested pathogens compared to untreated control. Soaking seeds in the bioagents combined with inducer chemicals reduced damping- off and root rot and/or wilt diseases severity than using any of them individually. The inducer chemicals were more effective in reducing damping-off and root rot and/or wilt diseases than the

Egypt. J. Phytopathol., Vol. 41, No. 2 (2013) 
Table 1. Pathogenicity test of fungi isolated from the roots of faba bean diseased plants

\begin{tabular}{|c|c|c|c|}
\hline Isolates No. & Damping-off $(\%)$ & Root rot and/or wilt (\%) & Survived plants (\%) \\
\hline \multicolumn{4}{|c|}{ Rhizoctonia solani } \\
\hline 1 & $18 \mathrm{j}^{*}$ & $25.33 \mathrm{f}$ & $56.67 \mathrm{e}$ \\
\hline 2 & $60 \mathrm{a}$ & $35.67 \mathrm{~d}$ & $4.33 \mathrm{n}$ \\
\hline 3 & $52 \mathrm{c}$ & $14.33 \mathrm{~h}$ & $33.67 \mathrm{i}$ \\
\hline 4 & $44 \mathrm{~d}$ & $12.69 \mathrm{hi}$ & $43.31 \mathrm{~g}$ \\
\hline 5 & $44 \mathrm{~d}$ & $39.67 \mathrm{c}$ & 16.331 \\
\hline \multicolumn{4}{|c|}{ Fusarium solani } \\
\hline 6 & $24 \mathrm{i}$ & $12.97 \mathrm{hi}$ & $63.03 \mathrm{~d}$ \\
\hline 7 & $28 \mathrm{~h}$ & $20.33 \mathrm{~g}$ & $51.67 \mathrm{f}$ \\
\hline 8 & $56 \mathrm{~b}$ & $33.60 \mathrm{~d}$ & $10.40 \mathrm{~m}$ \\
\hline 9 & $52 \mathrm{c}$ & $20.14 \mathrm{~g}$ & $27.86 \mathrm{j}$ \\
\hline \multicolumn{4}{|c|}{ Fusarium oxysporum } \\
\hline 10 & $32 \mathrm{~g}$ & $10.00 \mathrm{i}$ & $58.00 \mathrm{e}$ \\
\hline 11 & $40 \mathrm{e}$ & $35.00 \mathrm{~d}$ & $25.00 \mathrm{j}$ \\
\hline 12 & $36 \mathrm{f}$ & $50.67 \mathrm{a}$ & $13.30 \mathrm{~lm}$ \\
\hline 13 & $28 \mathrm{~h}$ & $44.33 \mathrm{~b}$ & $27.67 \mathrm{j}$ \\
\hline \multicolumn{4}{|c|}{ Macrophomina phaseolina } \\
\hline 14 & $50 \mathrm{c}$ & $28.67 \mathrm{e}$ & $21.33 \mathrm{k}$ \\
\hline 15 & $28 \mathrm{~h}$ & $12.67 \mathrm{hi}$ & $59.33 \mathrm{e}$ \\
\hline 16 & $40 \mathrm{e}$ & $22.54 \mathrm{fg}$ & $37.46 \mathrm{~h}$ \\
\hline 17 & $20 \mathrm{j}$ & $12.56 \mathrm{hi}$ & $67.44 \mathrm{c}$ \\
\hline \multicolumn{4}{|c|}{ Other fungi } \\
\hline 18 & 81 & $2.59 \mathrm{j}$ & $89.41 \mathrm{a}$ \\
\hline 19 & $4 \mathrm{~m}$ & $5.64 \mathrm{j}$ & $90.36 \mathrm{a}$ \\
\hline 20 & $12 \mathrm{k}$ & $5.28 \mathrm{j}$ & $82.72 \mathrm{~b}$ \\
\hline
\end{tabular}

* Different letters within the same column indicate significant differences among treatments according to least significant difference test $(\mathrm{P} \leq 0.05)$.

Table 2. Effect of the tested bioagents and the inducer chemicals individually or in combination on the in vitro linear growth of the tested fungi, 5 days after incubation at $25 \pm 1^{\circ} \mathrm{C}$

\begin{tabular}{|l|c|c|c|c|}
\hline \multirow{2}{*}{ Treatment } & \multicolumn{4}{|c|}{ Linear growth inhibition (\%) } \\
\cline { 2 - 5 } & $R$. solani & F. solani & F. oxysporum & M. phaseolina \\
\hline T. viride & $38.47 \mathrm{~d}^{*}$ & $55.58 \mathrm{c}$ & $44.69 \mathrm{~d}$ & $60.14 \mathrm{~b}$ \\
\hline B. megaterium & $32.33 \mathrm{e}$ & $49.22 \mathrm{~d}$ & $40.23 \mathrm{e}$ & $46.20 \mathrm{~d}$ \\
\hline Salicylic acid (SA) & $8.87 \mathrm{f}$ & $13.56 \mathrm{e}$ & $10.55 \mathrm{~g}$ & $11.58 \mathrm{f}$ \\
\hline Hydrogen peroxide $\left(\mathrm{H}_{2} \mathrm{O}_{2}\right)$ & $11.36 \mathrm{f}$ & $16.25 \mathrm{e}$ & $14.00 \mathrm{f}$ & $15.58 \mathrm{e}$ \\
\hline $\mathrm{SA}+$ T. viride & $57.00 \mathrm{a}$ & $70.54 \mathrm{a}$ & $62.35 \mathrm{a}$ & $64.30 \mathrm{a}$ \\
\hline $\mathrm{SA}+$ B. megaterium & $46.41 \mathrm{~b}$ & $63.25 \mathrm{~b}$ & $58.65 \mathrm{~b}$ & $56.36 \mathrm{c}$ \\
\hline $\mathrm{H}_{2} \mathrm{O}_{2}+$ T. viride & $42.24 \mathrm{c}$ & $59.25 \mathrm{bc}$ & $52.31 \mathrm{c}$ & $56.14 \mathrm{c}$ \\
\hline $\mathrm{H}_{2} \mathrm{O}_{2}+$ B. megaterium & $40.14 \mathrm{~cd}$ & $57.47 \mathrm{c}$ & $44.96 \mathrm{~d}$ & $53.34 \mathrm{c}$ \\
\hline
\end{tabular}

* Different letters within the same column indicate significant differences among treatments according to least significant difference test $(\mathrm{P} \leq 0.05)$. 
Table 3. Effect of soaking faba bean seeds in the preparations of the tested bioagents and inducer chemicals individually or in combination on controlling damping-off, root rot and survived plants under greenhouse conditions

\begin{tabular}{|c|c|c|c|c|c|c|c|c|}
\hline \multirow[b]{2}{*}{ Treatment } & \multicolumn{2}{|c|}{ R. solani } & \multicolumn{2}{|c|}{ F. solani } & \multicolumn{2}{|c|}{ F. oxysporum } & \multicolumn{2}{|c|}{ M. phaseolina } \\
\hline & 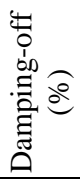 & $\underset{\substack{0 \\
0}}{\stackrel{0}{0}}$ & 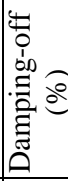 & 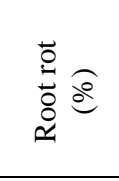 & 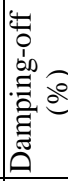 & 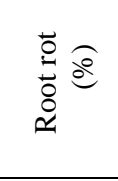 & 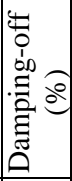 & $\stackrel{0}{0} \underset{0}{0}$ \\
\hline T. viride $(\mathrm{T})$ & $24 \mathrm{c}^{*}$ & $6.59 \mathrm{de}$ & $24 \mathrm{~b}$ & $8.67 \mathrm{bc}$ & $20 \mathrm{~b}$ & $18.23 \mathrm{~b}$ & $12 \mathrm{c}$ & $8.67 \mathrm{bc}$ \\
\hline B. megaterium $(\mathrm{B})$ & $28 \mathrm{~b}$ & $11.70 \mathrm{~b}$ & $20 \mathrm{c}$ & $10.23 \mathrm{~b}$ & $20 \mathrm{~b}$ & $20.23 \mathrm{~b}$ & $16 \mathrm{~b}$ & $10.33 \mathrm{~b}$ \\
\hline SA & $16 \mathrm{~g}$ & $7.67 \mathrm{~g}$ & $12 \mathrm{~h}$ & $6.47 \mathrm{f}$ & $12 \mathrm{f}$ & $12.36 \mathrm{f}$ & $8 \mathrm{f}$ & $6.67 \mathrm{e}$ \\
\hline $\mathrm{H}_{2} \mathrm{O}_{2}$ & $20 \mathrm{~d}$ & $8.90 \mathrm{c}$ & $16 \mathrm{~d}$ & $7.25 \mathrm{~cd}$ & $16 \mathrm{c}$ & $15.56 \mathrm{c}$ & $8 \mathrm{~d}$ & $10.33 \mathrm{~b}$ \\
\hline $\mathrm{SA}+(\mathrm{T})$ & $8 \mathrm{f}$ & $4.33 \mathrm{f}$ & $4 \mathrm{~g}$ & $3.60 \mathrm{e}$ & $4 \mathrm{f}$ & $6.36 \mathrm{e}$ & $4 \mathrm{e}$ & $5.6 \mathrm{~d}$ \\
\hline $\mathrm{SA}+(\mathrm{B})$ & $12 \mathrm{e}$ & $5.00 \mathrm{ef}$ & $8 \mathrm{f}$ & $5.67 \mathrm{~d}$ & $8 \mathrm{e}$ & $8.23 \mathrm{de}$ & $6 \mathrm{de}$ & $6.33 \mathrm{~d}$ \\
\hline $\mathrm{H}_{2} \mathrm{O}_{2}+(\mathrm{T})$ & $12 \mathrm{e}$ & $6.58 \mathrm{de}$ & $12 \mathrm{e}$ & $6.00 \mathrm{~d}$ & $12 \mathrm{~d}$ & $9.36 \mathrm{~d}$ & $6 \mathrm{de}$ & $6.33 \mathrm{~d}$ \\
\hline $\mathrm{H}_{2} \mathrm{O}_{2}+(\mathrm{B})$ & $12 \mathrm{e}$ & $6.89 \mathrm{~d}$ & $8 \mathrm{f}$ & $6.00 \mathrm{~d}$ & $8 \mathrm{e}$ & $10.25 \mathrm{~d}$ & $6 \mathrm{de}$ & $8.33 \mathrm{c}$ \\
\hline Control & $60 \mathrm{a}$ & $26.54 \mathrm{a}$ & $52 \mathrm{a}$ & $32.33 \mathrm{a}$ & $32 \mathrm{a}$ & $50.25 \mathrm{a}$ & $48 \mathrm{a}$ & $33.52 \mathrm{a}$ \\
\hline
\end{tabular}

* Different letters within the same column indicate significant differences among treatments according to least significant difference test $(\mathrm{P} \leq 0.05)$.

bioagents. On the other hand, the combination between SA and T. viride recorded the highest protection against any of the tested fungi followed by SA + $B$. megaterium, while seeds soaked in B. megaterium or $T$. viride recoded the lowest effect in this concern.

Effect of the bioagents and inducer chemicals on fresh and dry weight:

In the present study, using of the tested bioagents and the inducer chemicals individually or in combinations recorded significant increased to the fresh and dry weight of faba bean plants compared with control (Table 4). The combination between the bioagents and the inducer chemicals resulted in considerable increase to the fresh and dry weight more than using any of them individually. Also, the treatment with the bioagents gave fresh and dry weight higher than usage of the inducer chemicals. Generally, the combination between SA and T. viride recorded the highest fresh and dry weight of survived plants followed by $\mathrm{SA}+B$. megaterium. On other hand, the treatment with $\mathrm{H}_{2} \mathrm{O}_{2}$ recorded the lowest fresh and dry weights in this respect.

Effect of the bioagents and inducer chemicals on disease incidence under field conditions:

The efficacy of the inducer chemicals and bioagents individually and/or in combination as seed soaking against the incidence of damping-off as well as root rot and / or wilt diseases of faba bean, were evaluated under field conditions. Data in Table (5) clearly demonstrate that all treatments significantly reduced damping-off as well as root rot and/or wilt severity compared with the control. Soaking faba bean seeds in the preparation of the tested bioagents + inducer chemicals was more effective than using each alone. Also, the obtained data show that soaking the seeds 
Table 4. Effect of soaking faba bean seeds in the preparations of the bioagents and the inducer chemicals individually or in combination on fresh and dry weight (g/plant) of roots and shoots of faba bean plants

\begin{tabular}{|c|c|c|c|c|c|c|c|c|}
\hline \multirow{2}{*}{ Treatment } & \multicolumn{2}{|c|}{ R. solani } & \multicolumn{2}{|c|}{ F. solani } & \multicolumn{2}{|c|}{ F. oxysporum } & \multicolumn{2}{|c|}{ M. phaseolina } \\
\hline & $\mathrm{FW}^{*}$ & DW & FW & DW & FW & DW & FW & DW \\
\hline T. viride $(\mathrm{T})$ & $17.6 \mathrm{bc} * * *$ & $3.6 \mathrm{bc}$ & $16.8 \mathrm{cde}$ & $4.0 \mathrm{bcd}$ & $14.4 \mathrm{~cd}$ & $3.4 \mathrm{bc}$ & $17.7 \mathrm{~b}$ & $3.7 \mathrm{~b}$ \\
\hline B. megaterium (B) & $16.0 \mathrm{~cd}$ & $3.2 \mathrm{~d}$ & $15.2 \mathrm{de}$ & $3.5 \mathrm{de}$ & $13.9 \mathrm{de}$ & $3.2 \mathrm{c}$ & $16.6 \mathrm{~b}$ & $3.6 \mathrm{~b}$ \\
\hline SA & $14.8 \mathrm{f}$ & $3.0 \mathrm{f}$ & $12.3 \mathrm{~g}$ & $2.7 \mathrm{~g}$ & $10.6 \mathrm{~g}$ & $2.4 \mathrm{e}$ & $10.5 \mathrm{~d}$ & $2.2 \mathrm{~d}$ \\
\hline $\mathrm{H}_{2} \mathrm{O}_{2}$ & $13.6 \mathrm{~d}$ & $2.7 \mathrm{~d}$ & $14.2 \mathrm{e}$ & $3.2 \mathrm{e}$ & $11.7 \mathrm{e}$ & $3.1 \mathrm{c}$ & $10.1 \mathrm{c}$ & $2.0 \mathrm{c}$ \\
\hline $\mathrm{SA}+(\mathrm{T})$ & $21.2 \mathrm{a}$ & $4.1 \mathrm{a}$ & $21.1 \mathrm{a}$ & $4.7 \mathrm{a}$ & $18.4 \mathrm{a}$ & $4.0 \mathrm{a}$ & $22.3 \mathrm{a}$ & $4.8 \mathrm{a}$ \\
\hline $\mathrm{SA}+(\mathrm{B})$ & $20.2 \mathrm{ab}$ & $3.8 \mathrm{ab}$ & $20.0 \mathrm{ab}$ & $4.4 \mathrm{ab}$ & $17.4 \mathrm{ab}$ & $3.9 \mathrm{~b}$ & $19.3 b$ & $4.2 \mathrm{ab}$ \\
\hline $\mathrm{H}_{2} \mathrm{O}_{2}+(\mathrm{T})$ & $18.4 \mathrm{abc}$ & $3.5 \mathrm{bc}$ & 19.0abc & $4.1 \mathrm{bc}$ & $16.6 \mathrm{abc}$ & $3.6 a b c$ & $18.4 \mathrm{~b}$ & $4.0 \mathrm{~b}$ \\
\hline $\mathrm{H}_{2} \mathrm{O}_{2}+(\mathrm{B})$ & $16.8 \mathrm{c}$ & $3.2 \mathrm{~cd}$ & $17.5 \mathrm{bcd}$ & $3.8 \mathrm{~cd}$ & $15.4 \mathrm{bcd}$ & $3.4 \mathrm{bc}$ & $18.1 \mathrm{~b}$ & $3.8 \mathrm{~b}$ \\
\hline Control & $9.3 \mathrm{e}$ & $1.8 \mathrm{e}$ & $8.1 \mathrm{f}$ & $1.7 \mathrm{f}$ & $6.5 \mathrm{f}$ & $1.4 \mathrm{~d}$ & $9.1 \mathrm{c}$ & $1.8 \mathrm{c}$ \\
\hline
\end{tabular}

* $\mathrm{FW}=$ Fresh weight and FD= Dry weight

** Different letters within the same column indicate significant differences among treatments according to least significant difference test $(\mathrm{P} \leq 0.05)$.

Table 5. Effect of soaking faba bean seeds in the preparations of the tested bioagents and inducer chemicals individually or in combination on controlling damping-off, root rot and/or wilt and the survived plants under field conditions during 2010/11 and 2011/12 growing seasons

\begin{tabular}{|c|c|c|c|c|c|c|}
\hline \multirow[b]{2}{*}{ Treatment } & \multicolumn{3}{|c|}{ Season $2010 / 2011$} & \multicolumn{3}{|c|}{ Season $2011 / 2012$} \\
\hline & 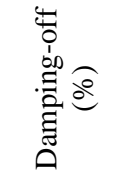 & $\underset{\substack{0 \\
0}}{\stackrel{0}{0}}$ & 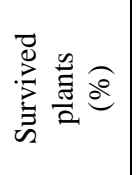 & 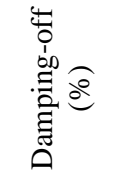 & $\underset{\substack{0 \\
0}}{\stackrel{0}{0}}$ & 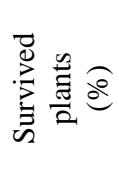 \\
\hline T. viride $(\mathrm{T})$ & $13.33 \mathrm{c}^{*}$ & $10.33 \mathrm{~b}$ & $76.34 \mathrm{ef}$ & $12.00 \mathrm{c}$ & $9.50 \mathrm{~b}$ & $78.50 \mathrm{ab}$ \\
\hline B. megaterium $(\mathrm{B})$ & $18.00 \mathrm{~b}$ & $10.00 \mathrm{bc}$ & $72.00 \mathrm{f}$ & $15.67 \mathrm{~b}$ & $9.33 \mathrm{~b}$ & $75.00 \mathrm{bc}$ \\
\hline SA & $9.67 \mathrm{~d}$ & $6.67 \mathrm{de}$ & $83.66 \mathrm{~cd}$ & $8.00 \mathrm{de}$ & $7.90 \mathrm{bc}$ & $84.10 \mathrm{ab}$ \\
\hline $\mathrm{H}_{2} \mathrm{O}_{2}$ & $10.67 \mathrm{~cd}$ & $7.96 \mathrm{~cd}$ & $81.37 \mathrm{de}$ & $10.00 \mathrm{~cd}$ & $6.33 \mathrm{~cd}$ & $83.67 \mathrm{ab}$ \\
\hline $\mathrm{SA}+(\mathrm{T})$ & $4.00 \mathrm{e}$ & $4.00 \mathrm{f}$ & $92.00 \mathrm{a}$ & $3.67 \mathrm{~g}$ & $3.00 \mathrm{e}$ & $93.33 \mathrm{a}$ \\
\hline $\mathrm{SA}+(\mathrm{B})$ & $5.67 \mathrm{e}$ & $5.26 \mathrm{ef}$ & $89.07 \mathrm{ab}$ & $5.00 \mathrm{fg}$ & $4.84 \mathrm{~d}$ & $90.16 \mathrm{ab}$ \\
\hline $\mathrm{H}_{2} \mathrm{O}_{2}+(\mathrm{T})$ & $7.33 \mathrm{de}$ & $4.33 \mathrm{f}$ & $88.34 \mathrm{abc}$ & $6.33 \mathrm{ef}$ & $5.00 \mathrm{~d}$ & $88.67 \mathrm{ab}$ \\
\hline $\mathrm{H}_{2} \mathrm{O}_{2}+(B)$ & $9.67 \mathrm{~d}$ & $5.50 \mathrm{ef}$ & $84.83 \mathrm{bcd}$ & $8.00 \mathrm{de}$ & $5.30 \mathrm{~d}$ & $86.70 \mathrm{ab}$ \\
\hline Control & $32.33 \mathrm{a}$ & $15.40 \mathrm{a}$ & $52.27 \mathrm{~g}$ & $28.00 \mathrm{a}$ & $13.00 \mathrm{a}$ & $59.00 \mathrm{c}$ \\
\hline
\end{tabular}

* Different letters within the same column indicate significant differences among treatments according to least significant difference test $(\mathrm{P} \leq 0.05)$.

in any of the tested inducer chemicals $\left(\mathrm{SA}\right.$ or $\mathrm{H}_{2} \mathrm{O}_{2}$ ) was more effective to reduce damping-off as well as root rot and/or wilt than soaking in any of the tested bioagents. In addition, $\mathrm{SA}+T$. viride recorded the highest redaction in damping-off as root rot and/or wilt in both seasons, where they recoded 92.0 and $93.33 \%$ survived plants compared with 52.27 and $59 \%$ in control plants in both seasons, respectively. In the contrary, faba bean seeds soaked in $B$. megaterium or $T$. viride recorded the lowest figures in both seasons, being 72.0 and $75 \%$ survived plants in first seasons and 76.34 and $78.50 \%$ in second season, respectively. 
Effect of bioagents and inducer chemicals on growth parameters, yield components and protein content under field conditions:

The effect of soaking faba bean seeds in the tested bioagents ( $T$. viride and B. megaterium) and inducer chemicals $\left(\mathrm{SA} \& \mathrm{H}_{2} \mathrm{O}_{2}\right.$ ) on growth parameters and yield components under field conditions during seasons of 2010/11 and 2011/12 were recorded in Table (6). Results indicate that seeds treated with the combination of the bioagents and inducer chemicals significantly improved the growth and branching more than using each of them individually. Also, soaking the seeds in any of the tested bioagents was more effective than using any of the inducer chemicals. The combination between SA and $T$. viride was the most effective treatment, where they recorded the highest plant height $(122.6 \& 132.4 \mathrm{~cm})$ and number of branches ( $4.1 \& 4.2$ branch plant $\left.^{-1}\right)$ in both seasons, respectively. Also, this treatment recorded the highest yield components, i.e. number of pods (19.3 \& 20.9 pods plant $\left.{ }^{-1}\right)$, number of seeds $\left(47.3 \& 53.2\right.$ seed $\left.^{\text {plant }}{ }^{-1}\right)$, weight of 100 seed $(83.9 \& 85.8 \mathrm{~g})$ and total seed yield $\left(1851 \& 1986 \mathrm{~kg}_{\text {feddan }}{ }^{-1}\right)$ in both seasons, respectively.

Table 6. Effect of soaking faba bean seeds in the preparations of the tested bioagents and the inducer chemicals individually or in combination on plant growth and yield parameters under field condition during 2010/11 and 2011/12 growing seasons

\begin{tabular}{|c|c|c|c|c|c|c|c|}
\hline \multirow[b]{2}{*}{ Treatment } & \multicolumn{7}{|c|}{ Season $2010 / 2011$} \\
\hline & 藏 & 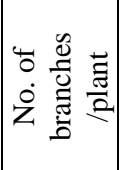 & 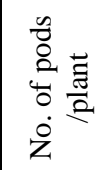 & 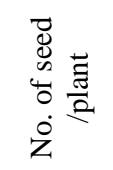 & 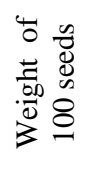 & 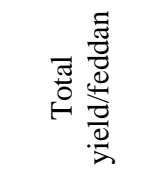 & 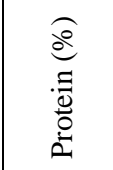 \\
\hline T. viride $(\mathrm{T})$ & $110.3 \mathrm{~cd}^{*}$ & $3.2 \mathrm{~cd}$ & $16.4 \mathrm{bc}$ & $41.5 \mathrm{~cd}$ & $80.9 \mathrm{a}$ & $1551.4 \mathrm{bd}$ & $28.3 \mathrm{abc}$ \\
\hline B. megaterium $(\mathrm{B})$ & $104.0 \mathrm{de}$ & $3.0 \mathrm{~d}$ & $14.5 \mathrm{~d}$ & $37.5 \mathrm{ef}$ & $81.2 \mathrm{a}$ & $1453.0 \mathrm{de}$ & $27.9 \mathrm{bc}$ \\
\hline SA & $98.5 \mathrm{e}$ & $3.3 \mathrm{~cd}$ & $15.0 \mathrm{~cd}$ & $36.4 \mathrm{f}$ & $81.6 \mathrm{a}$ & $1531.5 \mathrm{~cd}$ & $27.7 \mathrm{bc}$ \\
\hline $\mathrm{H}_{2} \mathrm{O}_{2}$ & $89.2 \mathrm{f}$ & $2.9 \mathrm{~d}$ & $13.6 \mathrm{de}$ & $34.8 \mathrm{f}$ & $79.9 \mathrm{a}$ & $1393.3 \mathrm{e}$ & $26.8 \mathrm{c}$ \\
\hline $\mathrm{SA}+(\mathrm{T})$ & $126.0 \mathrm{a}$ & $4.1 \mathrm{a}$ & $19.3 \mathrm{a}$ & $47.3 \mathrm{a}$ & $83.9 \mathrm{a}$ & $1851.0 \mathrm{a}$ & $30.8 \mathrm{a}$ \\
\hline $\mathrm{SA}+(\mathrm{B})$ & $119.6 \mathrm{~b}$ & $3.9 \mathrm{ab}$ & $17.4 \mathrm{~b}$ & $43.2 \mathrm{bc}$ & $82.5 \mathrm{a}$ & $1633.0 \mathrm{bc}$ & $29.7 \mathrm{ab}$ \\
\hline $\mathrm{H}_{2} \mathrm{O}_{2}+(\mathrm{T})$ & $115.3 \mathrm{bc}$ & $3.9 \mathrm{ab}$ & $17.3 \mathrm{~b}$ & $44.9 \mathrm{ab}$ & $82.9 \mathrm{a}$ & $1662.5 \mathrm{~b}$ & $28.1 \mathrm{abc}$ \\
\hline $\mathrm{H}_{2} \mathrm{O}_{2}+(\mathrm{B})$ & $109.5 \mathrm{~cd}$ & $3.6 \mathrm{bc}$ & $16.5 \mathrm{~b}$ & $39.2 \mathrm{de}$ & $82.1 \mathrm{a}$ & $1547.0 \mathrm{bcd}$ & $28.0 \mathrm{bc}$ \\
\hline Control & $70.3 \mathrm{~g}$ & $2.3 \mathrm{e}$ & $12.5 \mathrm{e}$ & $26.9 \mathrm{~g}$ & $72.4 \mathrm{~b}$ & $1060.0 \mathrm{f}$ & $26.1 \mathrm{c}$ \\
\hline \multicolumn{8}{|c|}{ Season $2011 / 2012$} \\
\hline T. viride $(\mathrm{T})$ & $117.2 \mathrm{~cd}$ & $3.2 \mathrm{c}$ & $17.0 \mathrm{bc}$ & $43.2 \mathrm{~cd}$ & $82.1 \mathrm{a}$ & $1644.5 \mathrm{~cd}$ & $28.6 \mathrm{bc}$ \\
\hline B. megaterium $(\mathrm{B})$ & $111.5 \mathrm{de}$ & $3.2 \mathrm{c}$ & $15.3 \mathrm{~cd}$ & 38.7 ef & $83.6 \mathrm{a}$ & $1537.2 \mathrm{de}$ & $27.4 \mathrm{~cd}$ \\
\hline SA & $103.5 \mathrm{f}$ & $3.4 \mathrm{c}$ & $17.3 \mathrm{bc}$ & $41.3 \mathrm{de}$ & $84.4 \mathrm{a}$ & $1604.0 \mathrm{~d}$ & $28.3 \mathrm{bc}$ \\
\hline $\mathrm{H}_{2} \mathrm{O}_{2}$ & $89.3 \mathrm{~g}$ & $2.8 \mathrm{~d}$ & $15.8 \mathrm{c}$ & $36.5 \mathrm{f}$ & $82.6 \mathrm{a}$ & $1475.8 \mathrm{e}$ & $27.4 \mathrm{~cd}$ \\
\hline $\mathrm{SA}+(\mathrm{T})$ & $132.4 \mathrm{a}$ & $4.2 \mathrm{a}$ & $20.9 \mathrm{a}$ & $53.2 \mathrm{a}$ & $85.8 \mathrm{a}$ & $1986.0 \mathrm{a}$ & $31.0 \mathrm{a}$ \\
\hline $\mathrm{SA}+(\mathrm{B})$ & $126.3 \mathrm{~b}$ & $3.9 \mathrm{ab}$ & $18.8 \mathrm{ab}$ & $47.3 \mathrm{~b}$ & $84.8 \mathrm{a}$ & $1758.7 \mathrm{~b}$ & $30.1 \mathrm{ab}$ \\
\hline $\mathrm{H}_{2} \mathrm{O}_{2}+(\mathrm{T})$ & $118.5 \mathrm{c}$ & $4.1 \mathrm{ab}$ & $18.6 \mathrm{~b}$ & $46.2 \mathrm{bc}$ & $84.2 \mathrm{a}$ & $1729.0 \mathrm{bc}$ & $28.7 \mathrm{abc}$ \\
\hline $\mathrm{H}_{2} \mathrm{O}_{2}+(\mathrm{B})$ & $110.4 \mathrm{e}$ & $3.8 \mathrm{~b}$ & $17.3 \mathrm{bc}$ & 39.9 def & $84.8 \mathrm{a}$ & $1552.5 \mathrm{de}$ & $27.8 \mathrm{bc}$ \\
\hline Control & $73.5 \mathrm{~h}$ & $2.4 \mathrm{e}$ & $13.5 \mathrm{~d}$ & $32.1 \mathrm{~g}$ & $75.6 \mathrm{~b}$ & $1202.8 \mathrm{f}$ & $25.2 \mathrm{~d}$ \\
\hline
\end{tabular}

* Different letters within the same column indicate significant differences among treatments according to least significant difference test $(\mathrm{P} \leq 0.05)$. 
On the contrary, $\mathrm{H}_{2} \mathrm{O}_{2}$ was less effective in both seasons compared with the other treatments. On the other hand, the obtained data show that all treatments significantly increased protein content in the seeds compared with untreated control. Also, $\mathrm{SA}+T$. viride recorded the highest protein content $(30.8 \& 31 \%)$ followed by $\mathrm{SA}+$ B. megaterium $(29.7 \& 30.1 \%)$ in both tested seasons, respectively. While, individually $\mathrm{H}_{2} \mathrm{O}_{2}$ recorded the lowest increase in this respect.

\section{D i s c u s s i on}

Faba bean (Vicia faba L.) is one of the most important legume crops. It is infected by many fungal pathogens causing considerable yield loss, where damping-off, root-rot and wilt diseases are the most important fungal diseases affecting its production in Egypt (Abdel-Kader et al., 2011).

Twenty isolates belonging to different soil-borne fungi were isolated from roots of faba bean plants showed root-rot and wilt symptoms collected from different fields located at New Valley Governorate. These isolates were purified and identified as Fusarium oxysporum, F. solani, Macrophomina phaseolina and Rhizoctonia solani.

Pathogenicity test of the obtained isolates revealed that all them could infect the roots of faba bean (cv. Giza 40) causing damping-off, root rot and/or wilt diseases and reduced the survived plants. Rhizoctonia solani (isolates 2 and 5), F. solani (isolate 8), F. oxysporum (isolate 12) and M. phaseolina (isolate 14) were the most virulent ones. These results are in harmony with those obtained by Metwally (2004) and Abdel-Kader et al. (2011).

Sustainable farming systems strive to minimize the use of synthetic pesticides and to optimize the use of alternative management strategies to control soil-borne pathogens (Harrier and Watson, 2004). Antagonistic fungi and bacteria in plant root zone are a key agent of change in soil agroecosystem. The interactions between plant root system and rhizobacteria have a profound effect on crop health, yield and soil quality. Root zone antagonistic fungi and bacteria are able to generate a wide array of secondary metabolites which can have a positive influence on plant growth; enhancing the availability of minerals nutrients, improving nitrogen fixation ability, decreasing susceptibility to frost damage, improving plant health through the biocontrol of phytopathogens, inducing systemic plant disease resistance and facilitating plant establishment, growth and development (Sturz and Christie, 2003). Also, acquired resistance by using abiotic-agents as inducers seems to be one of alternatives to substitute for, or at least to decrease the use of fungicides in plant disease control. Excessive and improper use of pesticides including fungicides presents a menace to the health of human, animal and environment (Guzzo et al., 1993). Plants respond to chemical elicitor treatments by activating a wide variety of protective mechanisms designed to prevent pathogen replication and spreading (Malolepsza and Rózalaska, 2005). The defence mechanisms include the fast production of reactive oxygen species (De Gara et al., 2003); alterations in the cell wall constitution; accumulation of antimicrobial secondary metabolites known as phytoalexins (Agrios, 2005); activation and/or synthesis of defence peptides and proteins (Castro and Fontes, 2005). In various plant species, resistance can be 
induced with elicitors such as salicylic acid and $\mathrm{H}_{2} \mathrm{O}_{2}$ against a wide range of pathogens (Abdel-Monaim 2010 and Abdel- Monaim et al., 2012).

In the present study, it was planning to investigate the possibility of minimizing the infection of damping-off, root-rot and wilt diseases on faba bean using bioagents (T. viride and $B$. megaterium) and inducer chemicals ( $\mathrm{SA}$ and $\mathrm{H}_{2} \mathrm{O}_{2}$ ) individually and/or in combinations as inducer resistance .

The obtained data revealed that both bioagents and inducer chemicals, individually and in combination, caused significant reduction to the in vitro linear growth of the tested pathogenic fungi. The combination between the bioagents and inducer chemicals were more effective in inhibiting the growth than using any of them individually, especially in case of $\mathrm{SA}+T$. viride and $\mathrm{SA}+B$. megaterium. On the other hand, all treatments caused significant reduction to both damping-off, root rot and/or wilt diseases, either in pots or in field experiments, compared with the control treatments. The combination between the bioagents and inducer chemicals was more effective in reducing damping-off as well as root rot and/or wilt severity and increased fresh and dry weight of the survived plants than using any of them individually. In this respect, treatments of $\mathrm{SA}+T$. viride and $\mathrm{SA}+$ $B$. megaterium gave the best results. These results are agree with those reported by many researchers (Metwally, 2004 and Abdel-Monaim, 2010). Saikia et al. (2003) tested the efficiency of $P$. fluorescens with or without SA amendment in chickpea against Fusarium wilt infection. The application of $P$. fluorescens (pf4-92) with SA recorded high protection to chickpea seedlings against wilt. Rajkumar et al. (2008) found that pepper seeds treated with the inducers SA and chitin each alone showed a moderate degree of plant protection against $R$. solani. However, the reduction in the disease was more pronounced when the inducers were applied with fluorescent pseudomonades (SE21 and RD41). They added that the amendment with chitin alone enhanced biocontrol efficiency of both SE21 and RD41. However, amendment with SA alone or in combination with chitin showed a moderate effect on biocontrol efficiency of the antagonists.

Seed soaking application of bioagents and chemical inducers individually or combination in both seasons showed significant increase in the growth parameters, yield components and protein content of the seeds. The combination between the bioagents and inducer chemicals recorded high increase in all growth and yield parameters more than when using each of them individually, especially $\mathrm{SA}+T$. viride and $\mathrm{SA}+B$. megaterium. These increments may be attributed to biotic and abiotic elicitors effect on physiological processes in the plant such as ion uptake, cell elongation, cell division, enzymatic activation and protein synthesis. In this concern, low SA and $\mathrm{H}_{2} \mathrm{O}_{2}$ doses enhanced growth and yield components of tomato (Abdel-Monaim et al., 2012), alfalfa (Morsy et al., 2011). Also, $B$. megaterium and $T$. viride increased plant growth and yield components in many plant species such as chickpea (Abdel-Monaim, 2010), dry bean (Yobo et al., 2011) and alfalfa (Morsy et al., 2011). The obtained results showed that the biocontrol efficiency of the antagonists $T$. viride and $B$. megaterium may be stimulated by SA and $\mathrm{H}_{2} \mathrm{O}_{2}$ resulting in a significant increase in their population density and antagonistic effect against the tested pathogens.

Egypt. J. Phytopathol., Vol. 41, No. 2 (2013) 
In conclusion, soaking faba bean seeds in the bioagent and inducer chemicals, either individually or in combination, significantly reduced damping-off as well as root rot and/or wilt and increased the survived plants either under greenhouse or field conditions. Also, these treatments increased plant growth, yield components and protein content in the seeds during both growing seasons (2010/11 and 2011/12). The combination between bioagents and inducer chemicals was better than using any of them individually, especially $\mathrm{SA}+T$. viride and $\mathrm{SA}+$ B. megaterium.

\section{Refre n c e c e}

Abdel-Kader, M. M.; El-Mougy, Nehal S. and Lashin S.M. 2011. Essential oils and Trichoderma harzianum as an integrated control measure against faba bean root rot pathogens. J. Plant Prot. Res., 51(3): 306-313.

Abdel-Monaim, M.F. 2010. Integrated management of damping-off, root and/or stem rot diseases of chickpea with sowing date, host resistance and bioagents. Egypt. J. Phytopathol., 38(1-2): 45-61.

Abdel-Monaim, M.F.; Abdel-Gaid, M.A. and Armanious, Hanaa A.H. 2012. Effect of chemical inducers on root rot and wilt diseases, yield and quality of tomato. International J. Agric. Sci., 2(7): 2011-2020.

Abdou, El-S., Abd-Alla, H.M. and Galal, A.A. 2001. Survey of sesame root rot and wilt disease in Minia and their possible control by ascorbic and salicylic acids. Assuit J. of Agric. Sci., 32(3): 135-152.

Agrios, G.N. 2005. Plant Pathology. $5^{\text {th }}$ Ed. Academic Press, San Diego, USA.

Anonymous, 1991. A Software Program for the Design, Management and Analysis of Agronomic Research Experiments. Michigan State University, 400 pp.

Barnett, H.L. and Hunter, B.B. 1986. Illustrated Genera of Imperfect Fungi. $4^{\text {th }}$ Ed., Macmillan Publishing Co., New York, USA.

Booth, C. 1985. The Genus Fusarium. $2^{\text {nd }}$ Ed., Kew, Surrey Commonwealth Mycological Institute, $237 \mathrm{pp}$.

Chaven j. K.; Kute, L.S. and Kadam, S.S. 1989. Pages: 223-245. In: CRC Hand Book of World Legumes. Salunkhe, D.D. and Kadam, S.S. (eds.). CRC Press, Boca Raton, Florida, USA.

De Boer, W.; Gerards, S.; Klein Gunnewiek, P.J.A. and Modderman, R. 1999. Response of the chitinolytic microbial community to chitin amendments of dune soils. Biol. Fertility Soils, 29: 170-177.

De Gara, L.; De Pinto, M.C. and Tommasi, F. 2003. The antioxidant systems vis-àvis reactive oxygen species during plant pathogen interaction. Plant Physiol. Biochem., 41: 863-870.

Dhingra, O.D. and Sinclair, J.B. 1985. Basic Plant Pathology Methods. CRC, Boca Raton, Florida, USA. 
Gomez, K.A. and Gomez, A.A. 1984. Statistical Procedures for Agricultural Research. A. Wiley-Interscience Publication. New York, USA. 678 pp.

Guzzo, S.D.; Back, E.A.; Martins, E.M. and Moraes, W.B. 1993. Crude expolysaccarides (EPS) from Xanthomonas campestris pv. maniohtis, Xanthomonas campestris pv. campestris and commercial xanthan gum as inducers of protection in coffee plants against Hemileia vastatrix. J. Phytopathol., 139: 119-128.

Harrier, L.A. and Watson, C.A. 2004. The potential role of arbuscular mycorrhizal (AM) fungi in the bioprotection of plants against soil-borne pathogens in organic and/or other sustainable farming systems. Pest Manage. Sci., 60(2): 149-157.

Jackson, M.L. 1973. Soil Chemical Analysis. Prentice Hall, New Delhi. India.

Jarvis, W.R. 1988. Fusarium crown root rot of tomatoes. Phytoprotection, 69: 49-64.

Liu, L.; Kloepper, J.W. and Tuzun, S. 1995. Introduction of systemic resistance in cucumber against Fusarium wilt by plant growth-promoting rhizobacteria. Phytopathology, 85: 695-698.

Malolepsza, U. and Rózalaska, S. 2005. Nitric oxide and hydrogen peroxide in tomato resistance. Nitric oxide modulates hydrogen peroxide level in O. hydroxyethylorutin-induced resistance to Botrytis cinerea in tomato. Plant Physiol. Biochem., 43: 623-635.

Metwally, M.M. 2004. Resistance induction against diseases of faba bean crop. Ph.D. Thesis, Fac. Agric., Suez Canal Univ.

Morsy, K.M. 2005. Induced resistance against damping-off, root rot and wilt diseases of lentil. Egypt. J. Phytopathol., 33(23): 53-63.

Morsy, K.M.; Abdel-Monaim, M.F. and Mazen M.M. 2011. Use of abiotic and biotic inducers in controlling fungal diseases and improving growth in alfalfa. Australian J. Basic Applied Sci., 5(9): 816-824.

Castro, M.S. and Fontes, W. 2005. Plant defence and antimicrobial peptides. Prot. Peptide Lett., 12: 11-16.

Muthomi, J.W.; Oteino, P.E.; Chemining, G.N.; Nderitu, J.H. and Wagacha, J.M. 2007. Effect of legume root rot pathogens and fungicide seed treatment on nodulation and biomass accumulation. J. Biological Sci., 7(7): 1163-1170.

Rajkumar M.; Lee, K.J. and Freitas, H. 2008. Effects of chitin and salicylic acid on biological control activity of Pseudomonas spp. against damping-off of pepper. South African J. Botany, 74: 268-273.

Roby, D.; Gadelle, A. and Toppan A. 1987. Chitin oligosaccharides as elicitors of chitinase activity in melon plants. Biochem. Biophysical Res. Communications, 143: 885-892.

Saikia, R.; Singh, T.; Kumar, R.; Srivastava, J.; Srivastava, A.K.; Singh, K. and Arora, D.K. 2003. Role of salicylic acid in systemic resistance induced by Pseudomonas fluorescens against Fusarium oxysporum f.sp. ciceri in chickpea. Microbiol. Res., 158: 203-213.

Egypt. J. Phytopathol., Vol. 41, No. 2 (2013) 
Saleh, N.M.; Hussan, A.K.; Sabir, L.J. and Aish, A.A. 2009. Evaluation the efficacy of baking yeast, some nutrients and salicylic acid to control Macrophomina phaseolina. The Iraqi. J. Agric. Sci., 40(6): 9-16.

Sturz, A.V. and Christie, R. 2003. Beneficial microbial allelopathies in the root zone: the management of soil quality and plant disease with rhizobacteria. Soil Tillage Res., 72(2): 107-123.

Yobo, K.S.; Laing, M.D. and Hunter, C.H. 2011. Effects of single and combined inoculations of elected Trichoderma and Bacillus isolates on growth of dry bean and biological control of Rhizoctonia solani damping-off. African $J$. Biotechnology, 10(44): 8746-8756.

(Received 22/07/2013;

in revised form 18/09/2013) 


\section{تحسين المكافحة الحيوية لأمراض سقوط البادرات

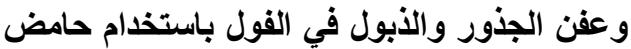 السالسليك وفوق أكسيد الإيدروجين

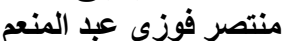 \\ معهد بحوث أمرئاض النباتات ـ مركز البحموث الزر اعية ـ جيزة ـ}

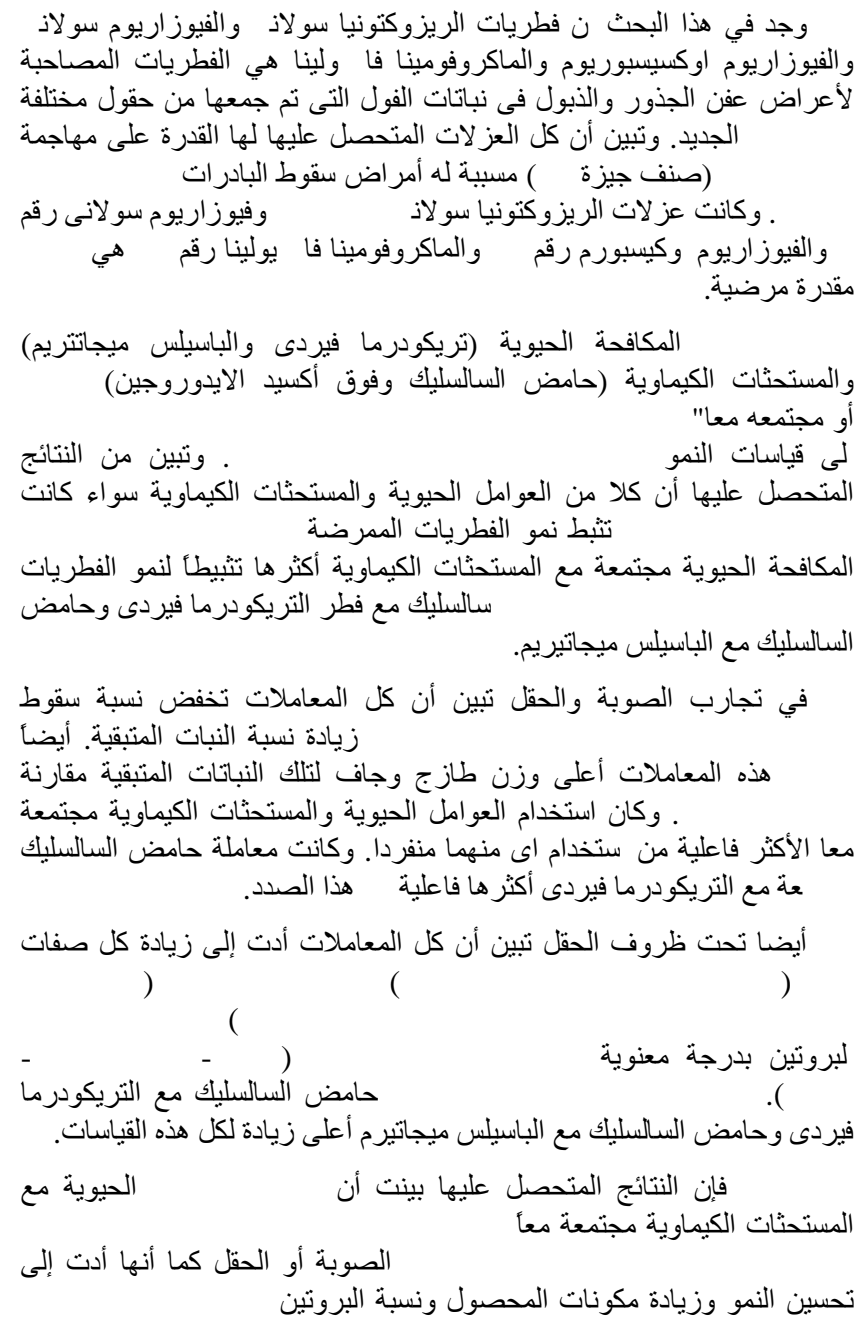

